\title{
PENGARUH REALISASI PENGELUARAN PEMERINTAH DAERAH TERHADAP PERTUMBUHAN EKONOMI DI SUMATERA BARAT
}

\author{
Yuliarti \\ Jurusan Ilmu Administrasi Negara, Fakultas Ilmu Sosial, Universitas Negeri Padang \\ uly.yuliarti@gmail.com
}

\begin{abstract}
To create positive economic growth and maintain economic stability, the role of the government is needed. The implementation of regional autonomy since early 2001 is a form of government strategy to encourage economic growth not only in the regions around the center but also in areas that are far from the center's reach. The implementation of regional autonomy is in accordance with Law No. 22 of 1999 concerning regional autonomy, as well as Law No. 32 of 2004 concerning local government. The government can regulate the course of the economy by determining the amount of government revenue and expenditure each year, which is reflected in the National Budget (APBN) for the national budget and the Regional Budget (APBD) for the region or region. This government expenditure is a form of fiscal policy. During the period of 2010-2019, it can be seen that the realization of the expenditure of the government of West Sumatra is more used for indirect expenditure than direct expenditure. For the average economic growth rate over the past ten years, West Sumatra has the second highest average growth rate compared to other provinces, which is $2.24 \%$, but the growth rate per year is still fluctuating and even more often decreases in percentage. Therefore, the authors are interested in examining how the influence of the realization of government spending on economic growth in West Sumatra. The purpose of this study is to find out how much influence the realization of government spending on economic growth in West Sumatra Province. This research uses quantitative data. The data analysis model used is simple linear regression and includes statistical tests. The results of the study show that government spending has a significant effect on economic growth in the province of West Sumatra.
\end{abstract}

Keywords: Goverment ekspendicture, economic growth

Submitted: March 21, 2020

Reviewed:April 2, 2020

Published: June 1, 2020

How to Cite: Yuliarti. 2020. Pengaruh Realisasi Pengeluaran Pemerintah Daerah Terhadap Pertumbuhan Ekonomi di Sumatera Barat. Vol 4 (1): pp. 136-147. DOI: https://doi.org/10.24036/jess/vol4-iss1

\section{Pendahuluan}

Pertumbuhan ekonomi merupakan merupakan salah satu indikator penting untuk mengevaluasi pembangunan yang telah dilaksanakan dan juga menjadi acuan dalam 
menentukan arah pembangunan dimasa yang akan datang. Pertumbuhan ekonomi yang positif menunjukkan adanya peningkatan perekonomian, sedangkan pertumbuhan ekonomi yang negatif menunjukkan adanya penurunan perekonomian.

Sebagai negara berkembang, peranan pemerintah masih sangat dibutuhkan untuk mendorong laju pertumbuhan perekonomian. Pelaksanaan otonomi daerah yang sudah terlaksana sejak awal tahun 2001 adalah salah bentuk strategi pemerintah untuk mendorong pertumbuhan ekonomi tidak hanya di daerah sekitar pusat tapi juga daerah-daerah yang jauh dari jangkauan pusat. Pelaksanaan otonomi daerah ini sesuai dengan Undang-Undang No.22 Tahun 1999 tentang otonomi daerah, serta Undang-Undang No. 32 Tahun 2004 tentang pemerintah daerah, yaitu hak, wewenang dan kewajiban daerah otonom untuk mengatur dan mengurus sendiri urusan pemerintahan dan kepentingan masyarakat setempat sesuai peraturan perundang-undangan.

Pada tabel 1 dibawah dapat dilihat perbandingan rata-rata pertumbuhan ekonomi diseluruh provinsi sumatera dan sumatera barat berada pada urutan kedua dengan nilai ratarata sebesar $2,24 \%$ dan provinsi sumatera selatan memiliki rata-rata pertumbuhan ekonomi paling tinggi yaitu sebesar $2,38 \%$. Sedangkan provinsi dengan rata-rata laju pertumbuhan ekonomi terendah adalah provinsi riau yaitu sebesar 1,10\% dan aceh sebagai provinsi kedua di sumatera dengan rata-rata laju pertumbuhan ekonomi terendah yaitu sebesar $1,72 \%$.

Tabel 1. Laju Pertumbuhan Ekonomi Daerah di Sumatera

Tahun 2010 - 2019

\begin{tabular}{lccccccccccc}
\hline Provinsi & $\mathbf{2 0 1 0}$ & $\mathbf{2 0 1 1}$ & $\mathbf{2 0 1 2}$ & $\mathbf{2 0 1 3}$ & $\mathbf{2 0 1 4}$ & $\mathbf{2 0 1 5}$ & $\mathbf{2 0 1 6}$ & $\mathbf{2 0 1 7}$ & $\mathbf{2 0 1 8}$ & $\mathbf{2 0 1 9}$ & Rata-Rata \\
Aceh & 2.74 & 4.84 & 5.14 & 4.18 & 1.65 & 2.14 & 3,29 & 4,18 & 4,61 & 4,15 & 1,72 \\
Sumut & 6.42 & 6.63 & 6.22 & 6.01 & 5.23 & 5.33 & 5,18 & 5,12 & 5,18 & 5,22 & 2,22 \\
Sumbar & 5.94 & 6.26 & 6.38 & 6.18 & 5.85 & 5.62 & 5,27 & 5,30 & 5,16 & 5,05 & 2,24 \\
Riau & 4.21 & 5.04 & 3.54 & 2.61 & 2.62 & 2.66 & 2,18 & 2,66 & 2,37 & 2,84 & 1,10 \\
Jambi & 7.76 & 7.86 & 7.03 & 6.84 & 7.35 & 4.21 & 4,37 & 4,60 & 4,74 & 4,40 & 1,99 \\
Sumsel & 5.63 & 6.5 & 6.01 & 5.98 & 4.68 & 4.57 & 5,04 & 5,51 & 6,04 & 5,71 & 2,38 \\
Bengkulu & 6.1 & 6.46 & 6.6 & 6.21 & 5.49 & 5.41 & 5,28 & 4,98 & 4,99 & 4,96 & 2,17 \\
Lampung & 5.88 & 6.43 & 6.53 & 5.97 & 5.08 & 4.9 & 5,14 & 5,16 & 5,25 & 5,27 & 2,23 \\
Babel & 5.99 & 6.5 & 5.73 & 5.29 & 4.68 & 4.76 & 4,10 & 4,47 & 4,46 & 3,32 & 1,78 \\
Kep.Riau & 7.19 & 6.66 & 6.82 & 6.13 & 7.32 & 7.89 & 4,98 & 1,98 & 4,58 & 4,89 & 1,83 \\
\hline Sumbr: Statikn
\end{tabular}

Sumber : Statistik Indonesia, berbagai edisi

Walaupun memiliki rata-rata laju pertumbuhan tertinggi kedua dibandingkan provinsi lain, laju pertumbuhan di provinsi sumatera barat berada pada kondisi yang berfluaktif bahkan lebih sering mengalami penururunan persentase. Laju pertumbuhan tertingi provinsi sumatera barat terjadi pada tahun 2012 yaitu sebesar 6,26 dan laju pertumbuhan terendah pada tahun 2019 yaitu sebesar 5,05\%.

Untuk menciptakan pertumbuhan ekonomi yang positif serta menjaga kestabilan ekonomi sangat dibutuhkan peran pemerintah. Kebijakan fiskal merupakan salah satu bentuk 
dari intervensi pemerintah dalam perekonomian yang diwujudkan melalui pengeluaran pemerintah (goverment expendicture). Melalui kebijakan ini, pemerintah dapat mengatur jalannya perekonomian dengan cara menentukan besarnya penerimaan dan pengeluaran pemerintah setiap tahunnya, yang tercemin dalam Anggaran Pendapatan Belanja Negara (APBN) untuk nasional dan Anggaran Pendapatan Belanja Daerah (APBD) untuk daerah atau regional.

Kebijakan pengeluaran pemerintah yang secara langsung dapat mendorong pertumbuhan ekonomi adalah belanja, karena dapat mewujudkan pembangunan prasarana ekonomi dan sosial. Perkembangan pengeluaran pemerintah yang diukur dari besarnya belanja langsung dan belanja tidak langsung. Pengklasifikasian belanja langsung dan tidak langsung ini digunakan dalam sistem penganggaran pemerintah baik pusat maupun daerah, yaitu sejak penerapan PP No.105 Tahun 2000 tentang pertanggung jawaban Pengelolaan Keuangan Daerah dan Kepmendagri No.29 Tahun 2002 yang kemudian direvisi menjadi PP No. 58 Tahun 2008 tentang Pengelolaan Keuangan Daerah dan Permendagri No.59 Tahun 2007 sebagai revisi Permendagri No.13 Tahun 2006 tentang Pedoman Pengelolaan Keuangan Daerah.

Berdasarkan tabel 2, diketahui realisasi belanja pemerintah daerah Provinsi Sumatera Barat cenderung mengalami penurunan. Pada tahun 2010 hingga tahun 2013 pengeluaran pemerintah mencapai pada nilai triliunan rupiah, dan pada tahun 2014 hingga 2019 pengeluaran pemerintah terhitung dalam miliar rupiah. Pengeluaran pemerintah dari belanja tidak langsung memiliki porsi yang lebih besar dibandingkan belanja langsung. Hal ini menunjukkan bahwa pemerintah daerah sumatera barat lebih banyak melakukan pengeluaran untuk belanja pegawai, bunga, subsidi, hibah, bantuan sosial dan sebagainya.

Tabel 2. Realisasi Belanja Daerah Provinsi Sumatera Barat 2010-2019

\begin{tabular}{crrrr}
\hline Tahun & $\begin{array}{c}\text { Belanja Tidak } \\
\text { Langsung }\end{array}$ & $\begin{array}{c}\text { Belanja Langsung } \\
\text { Pembiayaan Daerah }\end{array}$ & $\begin{array}{c}\text { Total Belanja } \\
\text { Daerah }\end{array}$ \\
2010 & $1.031 .743 .731 .385,00$ & $1.208 .009 .759 .735,88$ & $654.003 .320 .537,29$ & $2.893 .756 .811 .658,17$ \\
2011 & $1.087 .714 .687 .082,00$ & $1.045 .241 .836 .333,00$ & $310.247 .914 .014,00$ & $2.443 .204 .437 .429,00$ \\
2012 & $1.594 .693 .765 .223,00$ & $1.369 .888 .390 .409,59$ & $318.750 .283 .093,22$ & $3.283 .332 .438 .725,81$ \\
2013 & $1.668 .156 .981 .442,34$ & $1.445 .156 .683 .684,58$ & $205.750 .267 .365,96$ & $3.319 .063 .932 .492,88$ \\
2014 & $1.831 .872 .715,52$ & $1.651 .799 .638,01$ & $186.357 .418 .154,94$ & $189.841 .090 .508,47$ \\
2015 & $2.359 .421 .523,43$ & $1.662 .835 .436,95$ & $221.504 .643 .736,70$ & $225.526 .900 .697,08$ \\
2016 & $2.600 .444 .061,22$ & $1.903 .593 .197,54$ & $176.496 .991 .473,86$ & $181.001 .028 .732,62$ \\
2017 & $3.665 .975 .570,68$ & $2.093 .842 .821,72$ & $224.134 .278 .652,98$ & $229.894 .097 .045,38$ \\
2018 & $3.650 .739 .927,27$ & $2.616 .636 .303,82$ & $476.994 .083 .027,91$ & $483.261 .459 .259,00$ \\
2019 & $3.928 .859 .337,40$ & $2.622 .191 .365,82$ & $489.176 .382 .962,72$ & $495.727 .433 .665,94$ \\
\hline Sun
\end{tabular}

Sumber : BPS Sumbar, berbagai edisi 
Melihat kondisi ini maka penulis tertarik untuk melaksanakan penelitian mengenai Pengaruh Realisasi Pengeluaran Pemerintah terhadap Pertumbuhan Ekonomi di Provinsi Sumatera Barat.

Adapun rumusan masalah dalam penelitian ini adalah untuk mengetahui seberapa besar pengaruh pengeluaran pemerintah (realisasi) terhadap pertumbuhan ekonomi di provinsi sumatera barat. Dan tujuan penelitian ini adalah untuk menganalisis seberapa besar pengaruh pengeluaran pemerintah terhadap pertumbuhan ekonomi daerah di provinsi sumatera bara

\section{Tinjauan Kepustakaan}

\section{Pertumbuhan Ekonomi}

Pertumbuhan ekonomi (economic growth) secara paling sederhana dapat diartikan sebagai pertambahan output atau pertambahan pendapatan nasional agregat dalam kurun waktu tertentu misalkan satu tahun. Perekonomian suatu negara dikatakan mengalami pertumbuhan jika balas jasa rill terhadap penggunaan faktor-faktor produksi pada tahun tertentu lebih besar daripada tahun-tahun sebelumnya (Prasetyo, 2009). Sadono Sukirno (2012), mendefinisikan pertumbuhan ekonomi adalah perkembangan kegiatan ekonomi yang berlaku dari waktu ke waktu dan menyebabkan pendapatan nasional rill semakin meningkat.

Menurut Simon Kuznets dalam M.L Jhingan (2002) pertumbuhan ekonomi adalah peningkatan kemampuan suatu negara (daerah) untuk menyediakan barang-barang ekonomi bagi penduduknya, yang terwujud dengan adanya kenaikan output nasional secara terus menerus yang disertai dengan kemajuan teknologi serta adanya penyesuain kelembagaan, sikao dan ideologi yang dibutuhkannya. Hampir serupa dengan Simon Kuznets, menurut Todaro dan Smith (2006) pertumbuhan ekonomi merupakan suatu proses peningkatan kapasitas produktif dalam suatu perekonomian secara terus menerus atau berkesinambungan sepanjang waktu sehingga menghasilkan tingkat pendapatan dan output nasional yang semakin lama semakin besar. Menurut pandangan ekonom klasik, Adam Smiith, David Ricardo, Tomas Robert Malthus dan John Straurt Mill, maunpun ekonom neoklasik, Robert Solow dan Trevor Swan, mengemukakan bahwa pada dasarnya ada empat faktor yang mempengaruhi pertumbuhan ekonomi yaitu (1) jumlah penduduk, (2) jumlah stok barang modal (3) luas tanah dan kekayaan alam dam (4) tingkat teknologi yang digunakan.

Pertumbuhan ekonomi merupakan faktor penting dalam pembangunan, hal ini sesuai dengan teori yang diungkapkan oleh Tambunan (2001) bahwa pertumbuhan ekonomi yang tinggi dan prosesnya yang berkelanjutan merupakan kondisi utama bagi kelansungan pembangunan ekonomi. Pertumbuhan ekonomi menunjukkan sejauh mana aktivitas perekonomian akan menghasilkan tambahan pendapatan masyarakat pada suatu periode tertentu. Dengan kata lain, perekonomian dikatakan mengalami pertumbuhan bila pendapatan rill masyarakat pada tahun tertentu lebih besar dari pada pendapatan rill masyarakat sebelumnya. 
Pengukuran pertumbuhan ekonomi dapat dilihat dari pengingkatan persentase dari Produk Domestik Bruto (PDB) untuk nasional dan Produk Domesstik Regional Bruto (PDRB) untuk provinsi maupun kabupaten/kota. PDRB merupakan jumlah nilai tambah yang dihasilkan oleh selurut unit usaha dalam suatu wilayah tertentu atau merupakan jumlah nilai barang dan jasa akhir yang dihasilkam oleh unit ekonomi selama periode tertentu. Oleh karena itu, pertumbuhan ekonomi suatu wilayah dapat diperoleh melalui tingkat pertumbuhan nilai PDRB Atas Dasar Harga Konstan (ADHK).

Pertumbuhan ekonomi suatu daerah dapat diketahui dengan membandingkap PDRB Riil pada satu tahun tertentu (PDRBt) dengan PDRB tahun sebelumnya (PDRBt-1).

$$
\text { Laju Pertumbuhan Ekonomi }=\frac{P D R B_{t}-P D R B_{t-1}}{P D R B} \times 100 \%
$$

\section{Pengeluaran Pemerintahan}

Pengeluaran pemerintah mencerminkan kebijakan pemerintah. Apabila pemerintah telah menetapkan suatu kebijakan untuk membeli barang dan jasa, pengeluaran pemerintah mencerminkan biaya yang harus dikeluarkan oleh pemerintah untuk melaksanakan kebijakan tersebut (Mangkoesoebroto, 2002).

Pengeluaran pemerintah mempunyai dasar teori yang dapat dilihat dari identitas keseimbangan pendapatan nasional yaitu $\mathrm{Y}=\mathrm{C}+\mathrm{I}+\mathrm{G}+(\mathrm{X}-\mathrm{M})$ yang merupakan sumber legitimasi pandangan kaum Keynesian akan relevansi campur tangan pemerintah dalam perekonomian. Dari persamaan diatas dapat ditelaah bahwa kenaikan atau penurunan pengeluaran pemerintah akan menaikan atau menurunkan pendapatan nasional. Banyak pertimbangan yang mendasari pengambilan keputusan pemerintah dalam mengatur pengeluarannya (Dumairy, 2006).

Menurut UU No. 23 Tahun 2014 tentang Pemerintah Daerah, belanja daerah adalah semua kewajiban daerah yang diakui sebagai pengurang nilai kekayaan bersih dalam periode anggaran yang bersangkutan. Belanja daerah sebagaimana dimaksud dalam Peraturan Menteri Dalam Negeri Nomor 52 Tahun 2015 tentang Pedoman Pengelolaan Keuangan Daerah, menyebutkan bahwa belanja daerah dipergunakan dalam rangka mendanai pelaksanaan urusan pemerintah yang menjadi kewenangan provinsi atau kabupaten/kota yang terdiri dari urusan wajib, urusan pilihan dan urusan penanganannya dalam bagian atau bidang tertentu yang dapat dilaksanakan bersama antara pemerintah dan pemerintah daeraah atau antar pemerintah daerah yang ditetapkan berdasarkan peraturan perundang-undangan.

Teori pembangunan dan pengeluaran pemerintah dikembangkan oleh Rostow dan Musgrave yang menghubungkan pengeluaran pemerintah dan tahap-tahap pembangunan ekonomi yang dibedakan antara tahap awal, tahap menengah dan tahap lanjut. (1) Tahap awal, pada tahap awal perkembangan ekonomi persentase investasi besar, sebab pemerintah harus meyediakan prasarana, seperti pendidikan, kesehatan, pranasarana transportasi dan sebagainya. (2) Tahap menengah, investasi pemerintah tetap diperlukan untuk meningkatkan pertumbuhan ekonomi agara dapat tinggal landas, namun peranan investasi swasta sudah 
semakin membesar. (3) Tahap lanjut, pembangunan ekonomi dan aktivitas pemerintah beralih dari penyediaa prasarana ke pengeluaran-pengeluaran untuk aktivitas sosial seperti program kesejahteraan hari tua dan program pelayanan kesehatan masyarakat (Mangkoesoebroto, 2008).

\section{Hubungan Pengeluaran Pemerintah dan Pertumbuhan Ekonomi}

Pengeluaran pemerintah (goverment expendicture) adalah bagian dari kebijakan fiskal yakni suatu tindakan pemerintah untuk mengatur jalannya perekonomian dengan cara menentukan besarnya penerimaan dan pengeluaran pemerintah tiap tahunnya yang tercermin dalam dokumen APBN untuk nasional dan APBD untuk daerah/regional. Tujuan dari kebijakan fiskal ini adalah dalam rangka menstabilkan harga, tingkat output maupun kesempatan kerja dan memacu pertumbuhan ekonomi (Sukirno, 2008).

Teori klasik yang membahas pertumbuhan ekonomi yang dipengaruhi oleh peran pemerintah adalah Teori Klasik Keynes. Teori ini beranggapan bahwa campur tangan pemerintah dalam ekonomi menentukan pembangunan ekonomi dapat berjalan maksimal. Implikasi pandangan Keynes adalah bahwa untuk menjamin pertumbuhan yang stabil diperlukan peranan pemerintah dalam pengelolaan perekonomian baik melalui kebijakan moneter (tingkat suku bunga dan jumlah uang beredar) maupun kebijakan fiskal (perpajakan dan belanja pemerintah) (Sukirno, 2006).

Oleh karena itu, menurut Mangkoesoebroto (2002), di negara manapun selalu ada campur tangan atau intervensi pemerintah dalam perekonomian. Dalam perekonomian modern, peranan pemerintah dapat diklasifikasikan dalam tiga golongan besar, yaitu:

a. Peranan alokasi. Sumber daya yang dimiliki pada dasarnya dapat digunakan untuk menghasilkan barang swasta (private goods) dan barang publik (public goods) sehingga perlu dialokasikan oleh negara, seperti contohnya prasarana jalan, pertahanan, pembersihan udara dan sebagainya, yang pengadaannya perlu peran negara (pemerintah) di dalamnya;

b. Peranan distribusi. Melalui kebijakan fiskal, pemerintah dapat mengubah posisi distribusi pendapatan. Salah satu caranya adalah dengan menerapkan sistem pajak progresif yaitu beban pajak yang lebih besar dikenakan bagi orang kaya dan relatif lebih ringan bagi orang miskin, yang disertai dengan subsidi kepada kelompok miskin. Melalui subsidi, pemerintah secara tidak langsung bisa mempengaruhi distribusi pendapatan melalui kebijakan anggaran misalnya dengan memberikan kredit perumahan murah untuk golongan berpendapatan rendah, subsidi pupuk dan petani;

c. Peranan stabilitas. Selain peran alokasi dan distribusi, pemerintah mempunyai peran utama sebagai stabilator perekonomian. Hal ini dilakukan melalui berbagai regulasi. Pemerintah yang berupaya menjaga terpeliharanya tingkat kesempatan kerja yang tinggi, tingkat harga yang relatif stabil dan tingkat pertumbuhan ekonomi yang cukup memadai. 


\section{Metode Penelitian}

Penelitian ini merupakan penelitian kuantitatif asosiatif. Jenis data yang digunakan dalam penelitian data sekunder dari instasi terkait dan sumber-sumber yang relevan. Data dan informasi yang dikumpulkan berupa data time series yaitu Pengeluaran Pemerintah Daerah Sumatera Barat dan Pertumbuhan Ekonomi Sumatera Barat Tahun 2010-2019. Data yang diambil kemudian diolah dengan menggunakan program EVIEWS versi 11.

Model analisis yang digunakan dalam penelitian ini adalah regresi linear sederhana. Analisis ini digunakan untuk mengetahui arah hubungan antara variabel independen dan variabel depeneden apakah positif atau negatif, serta untuk memprediksi nilai dari variabel dependen apabila nilai variabel independen mengalami kenaikan atau penurunan. Salah satu metode yang digunakan untuk mengestimasi parameter model regresi yaitu metode kuadrat terkecil atau ordinary least square (OLS). Penggunaan metode OLS memerlukan beberapa asumsi klasik yang harus dipenuhi, dalam penelitian ini yaitu normalitas data, autokorelasi dan heterokedastisitas. Apabila asumsi klasik tersebut tidak terpenuhi, maka estimator yang dihasilkan bersifat bias dan interpretasi hasil yang diberikan pun menjadi tidak valid.

\section{Hasil dan Pembahasan}

\section{Uji Asumsi Klasik}

\section{Uji Normalitas}

Uji normalitas digunakan untuk menguji apakah nilai residual yang telah distarisasi pada model regresi berdistribusi normal atau tidak. Cara melakukan uji normalitas dapat dilakukan dengan pendekatan analisis grafik normal Probability Plot. Pada pendekatan ini nilai residual terdistribusi secara normal apabila garis (titik-titik) yang menggambarkan data sesungguhnya akan mengikuti atau merapat kegaris diagonalnya. 


\section{Tabel 3. Hasil Uji Normalitas}

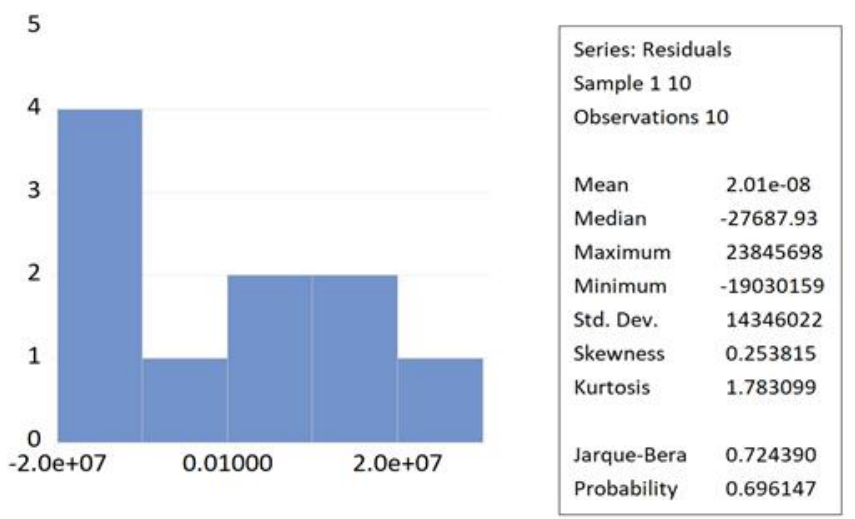

Sumber : Eviews 11, data diolah

Dari hasil uji diatas dapat dilihat bahwa nilai probability Jarque-Bera adalah sebesar 0,696147 lebih besar dari 0,05, artinya residual data dalam penelitian ini terdistribusi secara normal.

\section{Uji Autokorelasi}

Uji autokorelasi digunakan untuk mengetahui ada atau tidaknya penyimpangan asumsi klasik autokorelasi yaitu korelasi yang terjadi antara residual pada satu pengamatan dengan pengamatan lain pada model regresi. Model regresi yang baik adalah model regresi yang bebas dari autokorelasi. Autokorelasi dapat diketahui melalui uji Breusch-Godfrey, dimana jika nilai prob $<0,05$ maka terjadi gejala autokorelasi sedangkan jika nilai prob $>0,05$ maka tidak terjadi gejala autokorelasi.

\section{Tabel 4. Hasil Uji Autokorelasi}

\begin{tabular}{|c|c|c|c|}
\hline F-statistic & 1.246120 & Prob. $F(2,6)$ & 0.3527 \\
\hline ObsR-squared & 2.934726 & Prob. Chi-Square(2) & 0.2305 \\
\hline
\end{tabular}

Sumber : Eviews 11, data diolah

Pada tabel 4 diatas dapat dilihat bahwa nilai prob chi-square adalah sebesar 0,2305

Nilai uji ini lebih besar dari nilai signifikansi 0,05 sehingga dapat disimpulkan tidak terjadi gejala autokorelasi dalam penelitian ini.

\section{Uji Heterokedastisitas}

Heterokedastisitas yaitu adanya ketidaksamaan varian dari residual untuk semua pengamatan pada model regresi. Prasyarat yang harus terpenuhi dalam model regresi adalah tidak adanya 
gejala heterokedastisitas. Jika nilai prob $<0,05$ maka terjadi gejala heterokedastisitas sedangkan jika nilai prob $>0,05$ maka tidak terjadi gejala heterokedastisitas.

\section{Tabel 5. Hasil Uji Heterokedastisitas}

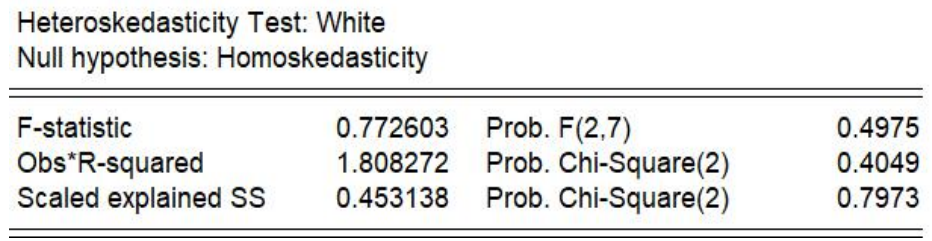

Sumber : Eviews 11, data diolah

Dari hasil uji heterokedastisitas dengan menggunakan metode white diatas, dapat disimpulkan tidak terjadi heterokedastisitas dalam penelitian ini. Hali ini dapat dibuktikan dengan nilai prob yang lebih besar dari nilai signifansi, yaitu 0,4049> 0,05 .

\section{Analisis Regresi Linear Sederhana}

Tujuan dari perhitungan regresi ini adalah untuk mengetahui bagaimana tingkat signifikansi pengaruh antara variabel bebas yaitu Pengeluaran Pemerintah (GE) terhadap variabel terikat yaitu Pertumbuhan Ekonomi (PDRB) Provinsi Sumatera Barat dengan tahun pengamatan 2010-2019. Hasil pengolahan dengan program EVIEWS versi 11, diketahui koefisien regresi sebagaimana pada tabel 6 berikut ini:

\section{Tabel 6. Hasil Analisis Regresi}

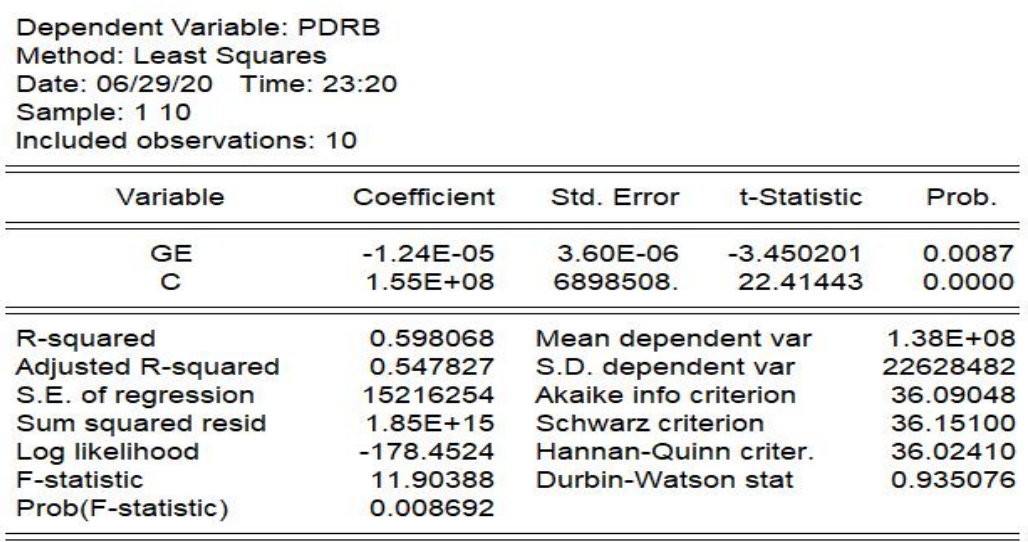

Sumber: Eviews 11, data diolah

Nilai koefisien regresi masing-masing variabel di atas dapat dituliskan ke dalam persamaan regresi linear sederhana sebagai berikut : 


$$
\mathrm{PDRB}=1.55+(-1.24) \mathrm{GE}
$$

Berdasarkan persamaan regresi tersebut maka dapat dijelaskan bahwa koefisien regresi negatif. Hal ini menunjukkan bahwa peningkatan realisasi pengeluaran pemerintah mempunyai efek negatif terhadap pertumbuhan ekonomi di Provinsi Sumatera Barat. Nilai koefisiensi regresi pengeluaran pemerintah (GE) sebesar -1,24, berarti apabila pengeluaran pemerintah (GE) mengalami kenaikan sebesar 1 persen, akan dapat mengakibatkan penurunan pertumbuhan ekonomi (PDRB) di Provinsi Sumatera Barat sebesar 1,24 persen, dengan asumsi variabel lain konstan (cateris paribus)

Dari hasil pengolahan data diatas juga dapat diketahui bahwa nilai prob variabel pengeluaran pemerintah (GE) adalah sebesar 0,0087 lebih kecil dari nilai signifikansi 0,05, Jadi dapat disimpulkan bahwa pengeluaran pemerintah (GE) berpengaruh signifikan terhadap pertumbuhan ekonomi (PDRB) di Sumatera Barat.

Pada tabel 6 R-Square menunjukkan suatu model regresi tersebut dapat digunakan untuk mengestimasi variabel yang diteliti. Nilai R2 $=0,5980$ menandakan bahwa variasi dari perubahan pertumbuhan ekonomi mampu dijelaskan oleh variasi perubahan realisasi pengeluaran pemerintah Provinsi Sumatera Barat sebesar 59,8 persen, sedangkan sisanya 40,2 persen dijelaskan oleh faktor-faktor lain yang tidak dibahas dalam model ini.

Setelah dilakukan analisis data penelitian maka selanjutnya dilakukan pembahasan terhadap analisis data. Dari anasilis data yang sudah dilaksanakan terlihat bahwa pengeluaran pemerintah berpengaruh signifikan terhadap pertumbuhan ekonomi di Sumatera Barat. Hasil penelitian ini sesuai dengan teori Rostow dan Musgrave yang menyatakan pada tahap pembangunan diperlukan investasi pemerintah yang digunakan untuk meningkatkan pertumbuhan ekonomi suatu daerah.

Menurut I Gede Dwi Purnama Putra dan I made Adigorim (2011) dalam penelitiannya, peningkatan pengeluaran pemerintah untuk belanja langsung menunjukkan kepedulian pemerintah akan perbaikan infrastur dan sarana publik, pengeluaran ini akan berdampak langsung untuk perekonomian. Sedangkan pengeluaran pemerintah untuk belanja tidak langsung memang tidak memiliki dampak secara langsung, namun dengan adanya pengeluaran pemerintah untuk belanja tidak langsung dapat memberikan dampak melalui pelayanan publik yang dilakukan pemerintah kepada masyarakat. Jamzani Sodik (2007) juga menemukan adanya pengaruh pengeluaran pembangunan terhadap pertumbuhan ekonomi, dalam penelitiannya pengeluaran pembangunan sama dengan belanja langsung karena kegunaannya sama-sama untuk memperbaiki infrastruktur dan fasilitas publik. Kemudian hasil penelitian ini juga sesuai dengan teori klasik Keynes yang menyatakan bahwa campur tangan pemerintah dalam ekonomi menentukan pembangunan ekonomi dapat berjalan maksimal. Implikasi pandangan Keynes adalah bahwa untuk menjamin pertumbuhan yang stabil diperlukan peranan pemerintah dalam pengelolaan perekonomian salah satunya melalui kebijakan fiskal (belanja). 


\section{Penutup}

Sesuai hasil temuan dan pembahsan yang sudah diuraikan sebelumnya maka dapat disimpulkan bahwa pengeluaran pemerintah (GE) memiliki pengaruh terhadap pertumbuhan ekonomi (PDRB) di provinsi Sumatera Barat. Hal ini terlihat dari nilai signifikansi pengeluaran pemerintah terhadap pertumbuhan ekonomi yang lebih kecil dari $\alpha=5 \%$. Untuk menciptakan pertumbuhan ekonomi yang positif maka pemerintah perlu memperbesar alokasi belanja langsung karena dalam belanja langsung terdapat belanja barang dan jasa serta belanja modal yang memiliki dampak secara langsung dengan pelaksanaan program dan kegiatan pemerintah, tentu kita berharap setiap program dan kegiatan yang dilaksanakan oleh pemerintah memiliki tujuan untuk kesejahteraan masyarakat salah satu melalui pertumbuhan ekonomi yang positif.

\section{DAFTAR KEPUSTAKAAN}

\section{Buku dan Jurnal}

Dumairy (2006). Perekonomian Indonesia. Jakarta : Erlangga

Jhingan, ML. 2002. Ekonomi Pembangunan dan Perencanaan . PT. Raja Grafindo Persada. Jakarta.

Mangkoesoebroto. Guritno, (2002). Ekonomi Publik. Yogyakarta : PBFE -, (2008). Ekonomi Publik. Edisi Ketiga. Yogyakarta : PBFE

Putra, I Gede Dwi Purnama, Adigorim. 2011. Pengaruh Belanja Langsung dan Belanja Tidak Langsung Terhadap Pertumbuhan Ekonomi. E-Jurnal Ekonomi Pembangunan, Universitas Udayana, Bali. Vol.1, No.2, Desember 2012

Sodik, Jamzani. 2007. "Pengeluaran Pemerintah dan Pertumbuhan Ekonomi Regional: Studi Desa Data Panel Indonesia". Jurnal Ekonomi Pembangunan, Vol.12, No.1, April 2007, UPN "Veteran" Yogyakarta.

Sukirno, Sadono. 2006. Makroekonomi: Teori Pengantar. Edisi Ketiga. Jakarta : Rajawali Press 2008. Makroekonomi Modern, Perkembangan Pemikiran dari Klasik Hingga Keynesian Baru. PT. Raja Grafindo Persada. Jakarta. , 2013. Pengantar Teori Makroekonomi. PT. Raja Grafindo Persada. Jakarta.

Prasetyo, P. Eko 2009. Fundamental Makro Ekonomi. Beta Offset, Yogyakarta

Tambunan, Tulus. 2001. Perekonomian Indonesia : Teori dan Temuan Empiris. Jakarta : Ghalia Indonesia

Todaro, M.P. dan S.C. Smith. 2006. Pembangunan Ekonomi di Dunia Ketiga Jilid I \& II. Terjemahan. Jakarta : Erlangga

Peraturan Perundang-undangan dan Sumber Dokumentasi

Undang-Undang No 22 Tahun Tahun 1999 Tentang Pemerintah Daerah

Undang-Undang No 32 Tahun 2014 Tentang Pemerintah Daerah 
Undang-Undang No. 23 Tahun 2014 tentang Pemerintah Daerah

Peraturan Pemerintah No 105 Tahun 2000 Tentang Pertanggung jawaban Pengelolaan Daerah Permendagri No.59 Tahun 2007 Tentang Pedoman Keuangan Daerah

Permendagri Nomor 52 Tahun 2015 tentang Pedoman Pengelolaan Keuangan Daerah

Sumbar.bps.go.id 